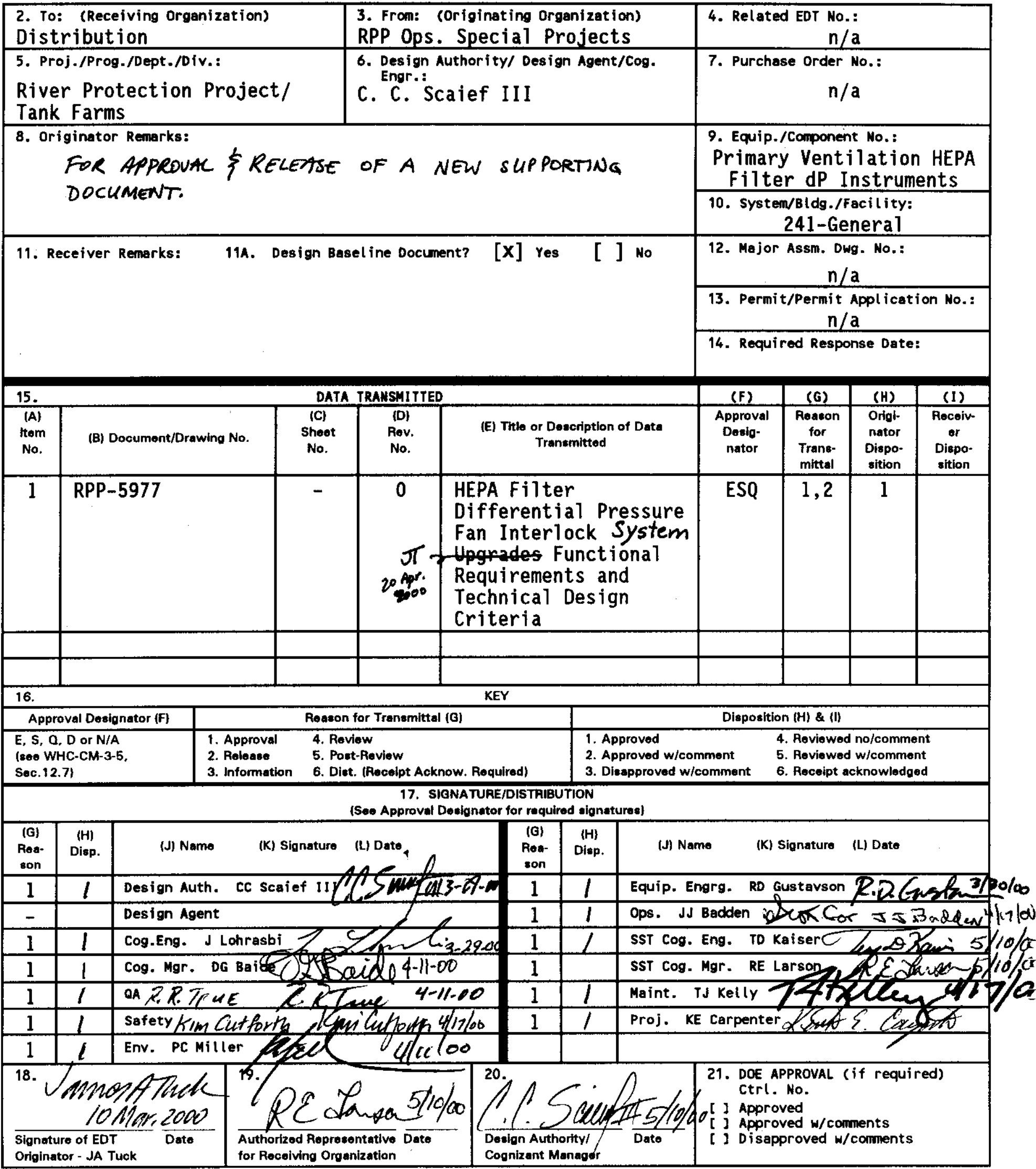




\section{HEPA Filter Differential Pressure Fan Interlock System Functional Requirements and Technical Design Criteria}

James A. Tuck

for: CH2M-Hill Hanford Group, Inc., Richland, WA 99352

U.S. Department of Energy Contract DE-AC06-96RL13200

EDT/ECN: 626597

Org Code: LP200000/7C200

B\&R Code: EW313000
UC: $n / a$

Charge Code: CACN 102613

Total Pages: 13

Key Words: HEPA, high-efficiency particulate air filter, differential pressure, exhauster, ventilation, primary ventilation, interlock, filter failure, filter breach, spray leak.

Abstract: This document defines the initial technical design baseline for a $H E P A$ filter $\Delta P$ fan interlock system.

TRADEMARK DISCLAIMER. Reference herein to any specific commercial product, process, or service by trade name, trademark, manufacturer, or otherwise, does not necessarily constitute or imply its endorsement, recommendation, or favoring by the United states Goverment or any agency thereof or its contractors or subcontractors.

Printed in the United States of America. To obtain copies of this document, contact: Document Control Services, P.0. Box 950, Mailstop H6-08, Richland WA 99352, Phone (509) 372-2420; Fax (509) 376-4989.
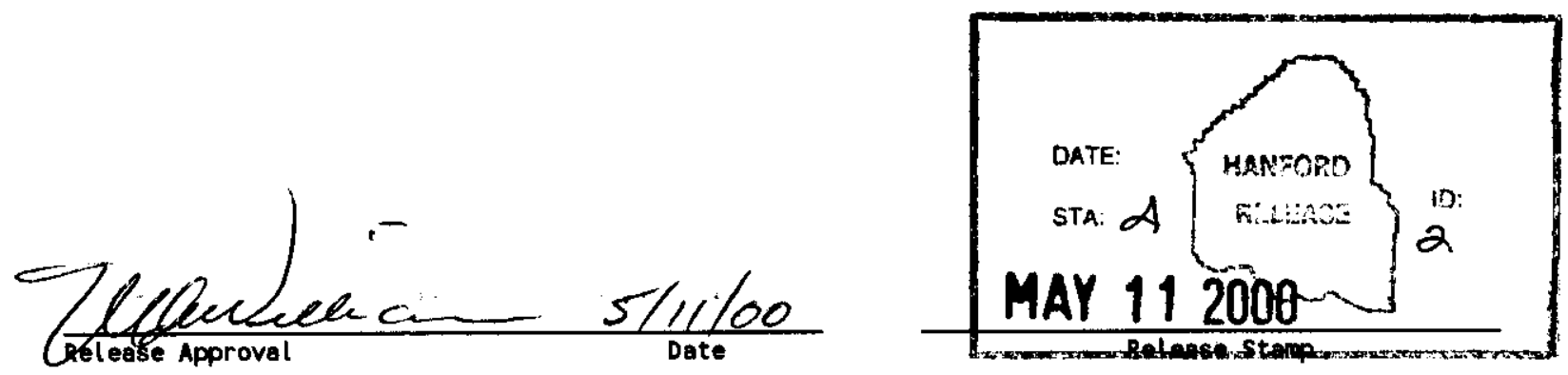

Approved for Public Release 
RPP-5977, Rev. 0

\section{CONTENTS}

1.0 INTRODUCTION AND SCOPE $\ldots \ldots \ldots \ldots$

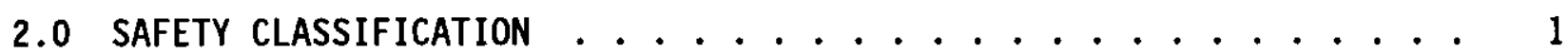

3.0 APPLICABLE REFERENCES . . . . . . . . . . . . 2

4.0 FUNCTIONS AND REQUIREMENTS .................. 3

4.1 System Definition .................. 4

4.2 Characteristics ............... 4

4.3 General Technical Design Criteria ........... 5

4.4 Civil Engineering and Site Work ............ 6

4.5 Mechanical Engineering and Materials ........ 6

4.6 Electrical, Instrumentation, and Controls ........ 6

4.7 Safety ................... 7

4.8 Human Engineering . . . . . . . . . . . . . . . 7

4.9 Qualification ................ 7

5.0 QuAlitY ASSURANCE . . . . . . . . . . . . . . . 7

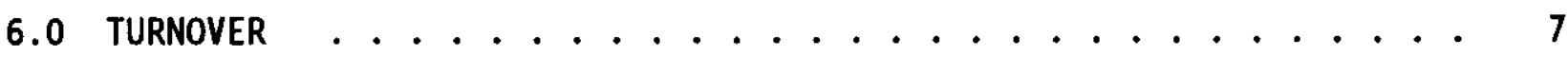

7.0 APPENDICES ............................. 8

7.1 List of Affected Exhausters $\ldots \ldots$

7.2 Reference Drawings . . . . . . . . . . . . . 9 


\section{FUNCTIONAL REQUIREMENTS AND TECHNICAL DESIEN CRITERIA FOR A HEPA FILTER AP FAN INTERLOCK SYSTEM}

\subsection{INTRODUCTION AND SCOPE}

Double-shell tanks (DSTs) and Double Contained Receiver Tanks (DCRTs) are actively ventilated, along with certain single-shell tanks (SSTs) and other RPP facilities. The exhaust air stream on a typical primary ventilation system is drawn through two stages of high-efficiency particulate air (HEPA) filtration to ensure confinement of airborne radioactive materials. Active ventilation exhaust stacks require a stack CAM interlock to detect releases from postulated accidents, and to shut down the exhaust fan when high radiation levels are detected in the stack airstream. The stack CAM interlock is credited as a mitigating control to stop continued unfiltered radiological and toxicological discharges from the stack, which may result from an accident involving failure of a HEPA filter.

Recently, it has been determined that an alternative system, based on monitoring HEPA filter differential pressure (DP, or $\Delta P$ ), is technically equivalent to the stack CAM interlock and can perform its safety function (Gustavson 2000; ORP 2000). The alternative system can provide the requisite level of control specified in the facility safety analysis, and is expected to provide this function more reliably and with fewer operational and maintenance problems. Expected benefits include improved operating safety, reduced operating cost, and more reliable waste transfers or waste feed delivery. The tank farms operating contractor has been directed by DOE to implement the alternative system on active ventilation systems in the process area applicability statement of LCO 3.1.4 of HNF-SD-WM-TSR-006 (ORP 1999). Seven of these upgrades are planned for the current fiscal year, and the remainder are planned for completion in FY 2001. The applicable locations are listed in Section 7.1.

This document defines the initial technical baseline for design of an alternative $\Delta$ P-based interlock system.

\subsection{SAFETY CLASSIFICATION}

The HEPA Filter $\triangle P$ Fan Interlock System will functionally replace the Ventilation Stack CAM Interlock System, which is required by the current facility safety analysis and Technical Safety Requirement (TSR) LCO 3.1.4. Therefore, the new system will be Safety Significant (SS) for postulated HEPA Filter Failure accidents caused by excessive pressure or temperature (FSAR Section 3.3.2.4.2 and Addendum 1, Sections 3.4.2.2 and 3.4.2.3), and Safety Class (SC) for HEPA filter failure caused by moisture loading from a postulated Spray Leak accident (FSAR Section 3.4.2.9). Therefore, new system must provide the following $S S$ safety function:

The HEPA Filter $\triangle P$ Interlock System shall activate an interlock to shut down the ventilation system automatically when $\Delta^{p}$ across the last HEPA filter stage reaches a preset low limit, indicating a gross filter failure. 
The applicable process area for this SS function is limited to active primary ventilation systems on DSTs and SSTs (including 241-C-105/106, 241-SX, and portable exhausters).

In addition, new system must provide the following Safety Class (SC) safety function:

The HEPA Filter $\triangle P$ Interlock System shall activate an interlock to shut down the ventilation system automatically when $\Delta^{p}$ across the upstream (first) HEPA filter stage reaches a preset high limit, indicating an impending filter failure.

The applicable process area for this SC function includes all DST primary and SST active ventilation systems, as well as portable primary tank exhausters and exhausters on DCRTs, 244-CR Vault, and the 204-AR Waste Unloading facility.

Note that both the $\Delta P$ limits and response time of the $\Delta P$ interlock system are parameters to be determined based on an accident analysis. As part of the proposed upgrade, the tank farms Authorization Basis (AB) will be revised to credit this alternative system. Note, also, in the case of the 204-AR facility, due to unique aspects of its ventilation system configuration, the Safety Class safety function may apply to the last HEPA filter stage instead of the first; this is to be clarified in the $A B$ amendment.

Both the CAM interlock and the proposed alternative $\Delta P$ interlock system are mitigating controls intended to limit radiological releases following a variety of HEPA filter failure accidents, indicated by low filter $\Delta P$. The $\Delta P$ interlock system can provide an additional, preventative control for the Spray Leak accident, by shutting down the fans on high $\Delta P$. In this case, the system is credited with reducing the likelihood of failure of a HEPA filter saturated with aerosol from the spray leak, reducing the likelihood of HEPA filter failure due to a postulated Spray Leak in Structure accident (FSAR Sec. 3.4.2.9), and preventing the release of radiological and toxicological materials.

To perform its safety functions, the $\Delta P$ interlock system must be continuously operable and it must fail in a safe condition (exhauster shut down) upon a loss of power or a detectable failure.

The boundary of the Safety Class (or Safety Significant) portions of the system shall be defined to help identify any additional design criteria and to facilitate procurement and maintenance of the system. Safety classification shall also be determined for supporting systems, including electrical power. Facility safety equipment lists will be revised accordingly.

\subsection{APPLICABLE REFERENCES}

[See also Section 7.2 for a list of facility reference drawings]

Industry Consensus Standards (use currently site-adopted revisions):

NFPA 70-1999, National Electric Code, National Fire Protection Association. 
Authorization Basis Documents:

HNF-SD-WM-SAR-067, TWRS Final Safety Analysis Report (FSAR), CH2M-Hill Hanford Group, Inc., Richland, Washington.

HNF-SD-WM-TSR-006, TWRS Technical Safety Requirements (TSRs), CH2M-Hill Hanford Group, Inc., Richland, Washington.

Other Requirements and Supporting Documentation:

Gustavson, R. D., 2000, Evaluation of Alternative Control for Prevention or Mitigation of HEPA Filter Failure Accidents at Tank Farm Facilities, RPP-5594, CH2M Hill Hanford Group, Inc., Richland, Washington.

HESP, 2000, Electrical Safety Compliance Guide: NRTL Requirements for Electrical Equipment, ESCG-2000-01, 13 Apri1 2000, Hanford Electrical Safety Program (HECB - HWESB), Hanford Works, Richland, Washington.

HNF-IP-0842, RPP Administration, Volume IV, "Engineering", CH2M-Hill Hanford Group, Inc., Richland, Washington.

HNF-IP-1266, Tank Farms Operations Administrative Controls, CH2M-Hil1 Hanford Group, Inc., Richland, Washington.

ORP, 1999, Implementation of Field Optimization, Contract No. DE-ACO699RL14047, FY 2000 Performance Incentive ORP 3.2.3, Rev. 0, U.S. Department of Energy Office of River Protection, Richland, Washington.

ORP, 2000, Contract No. DE-AC06-99RL14047 - Partial Completion of Fiscal Year (FY) 2000 Performance Incentive ORP 3.2.3, Standard 2, and Section 4.2(a), Letter 00-TSD-012, J. J. Short to M. P. DeLozier, 15 February 2000 .

RPP-MP-599, Project Hanford Quality Assurance Program Description, CH2M-Hill Hanford Group, Inc., Richland, Washington.

RPP-PR0-97, Engineering Design and Evaluation, CH2M-Hill Hanford Group, Inc., Richland, Washington.

RPP-PRO-309, Computer Software Quality Assurance Requirements, CH2M-Hill Hanford Group, Inc., Richland, Washington.

RPP-PRO-3144, Supplier Quality Assurance Program Evaluation, CH2M-Hill Hanford Group, Inc., Richland, Washington.

Simons, S. R., 2000, Engineering Task Plan for HEPA Filter Differential Pressure (DP) Fan Interlock Upgrades, RPP-6180, CH2M Hill Hanford Group, Inc., Richland, Washington. 
RPP-5977, Rev. 0

\subsection{FUNCTIONS AND REQUIREMENTS}

\subsection{System Definition}

A differential pressure $(\Delta P)$ interlock system shall be provided that measures HEPA filter air flow resistance, or pressure drop, and performs the safety related interlock functions described in Section 2.0 of this document.

The $\Delta P$ interlock system shall be of a generic design, capable of being installed and operated on facility ventilation systems at multiple locations (listed in Section 7.1, below) with minor site-specific engineering.

The system shall measure $\triangle P$ across the "first" (i.e., upstream) HEPA filter stage, the "second" (i.e., downstream) HEPA filter stage, and the combined $\triangle P$ across the filter train (i.e., both HEPA filter stages in series). The system shall provide capability to alarm and activate an interlock to shut down the ventilation fan at predetermined $\Delta P$ setpoints across either or both filter stages. The system shall also measure $\Delta \mathrm{P}$ across the prefilter, providing local indication for maintenance and surveillance purposes, in those cases where existing systems have this local indication.

The actual $\Delta \mathrm{P}$ limits and operating modes for the proposed system shall be based on an approved $A B$ change (TSR controls). The ideal system design will provide the flexibility to support a reasonable range of operational settings, alarms, and interlocks to be dictated by such analysis. A discussion of how differential pressure is generated and what limitations exist, in relation to proposed TSR limits, is included in a recent engineering evaluation

(Gustavson 2000).

The system shall have the capability to act on both low and high $\Delta \mathrm{P}$ interlock setpoints. The system shall provide a remote alarm display for each interlock state (i.e., tie-in to a local control room alarm pane1), to enable operators to ascertain the cause of the system shutdown prior to entering the facility.

Based on future safety analysis and potential requirements that may be imposed on the system design, there may be a need for the capability to track rate of change in filter $\Delta P$, and to initiate the interlock to shut down the fan at a preset "rate-of-change" condition. Additional design features, including sufficient memory, would be needed to provide this capability in addition to the required low and high $\Delta \mathrm{P}$ interlocks. Actual implementation of this feature is not a current design requirement for the system. However, either

the current design shall provide the additional capability to be configured as a fan interlock based on the "rate-of-change" of filter $\Delta P$, or it shall not preclude adding this feature in the future.

Additionally, a desired feature of the $\Delta \mathrm{P}$ interlock system is the capability to track the rate of change in the various filter $\Delta P$ readings over time for diagnostic purposes. These parameters should be accessible via a portable computer or equivalent means.

\subsection{Characteristics}

The $\Delta P$ interlock system design shall utilize $\Delta P$ transmitters to monitor pressure drop across the HEPA filters, and a programmable logic controller 
(PLC) to provide necessary signal processing, data acquisition, and control functions for the system, and to house the setpoints for alarms and interlocks. The PLC shall utilize a 24-Volt DC power supply, and shall have expansion capabilities.

The $\Delta \mathrm{P}$ transmitters shall measure pressure differentials over a range and at an accuracy to be determined in definitive design. In addition, the $\Delta P$ transmitter shall provide a local digital display readable in units of inches of water column (in. w.c.) to the nearest 0.01 in. w.c. The selection of a specific $\Delta P$ transmitter model shall consider existing equipment within tank farms, which is supported by plant procedures, operator and crafts familiarity, and consistent design application.

The $\Delta P$ interlock system shall have a serial interface port available for future communications with a supervisory control system (e.g., TMACS).

A control program shall be developed based on system operational requirements, and the program shall be verified and validated in accordance with applicable procedures. A software configuration management plan shall be developed to control any changes to the program logic. The requirements for verification, validation, and configuration management of software are provided in RPP-PR0-309.

The system shall provide means of signal conditioning, or the ability to adjust or dampen the signal to prevent spurious alarms and shutdowns.

The $\Delta P$ setpoints shall be adjustable to accommodate changes in established operating specifications, based on further accident analysis or operating experience.

\subsection{General Technical Design Criteria}

The design shall comply with the requirements defined in this document. The criteria of DOE $6430.1 \mathrm{~A}$, General Design Criteria, shall be applied to the design as deemed appropriate by the Design Authority; the applicability of DOE $6430.1 \mathrm{~A}$ criteria to RPP facilities is the subject of ongoing evaluation.

The $\Delta P$ interlock system shall be designed for year-round operation in an outdoor environment at the Hanford site. Environmental conditions to consider in the design and selection of components shall include exposure to sunlight, rain, frozen precipitation, wind, blowing sand and dust, and ambient air temperatures ranging from $-25^{\circ} \mathrm{F}\left(-32^{\circ} \mathrm{C}\right)$ to $115^{\circ} \mathrm{F}\left(46^{\circ} \mathrm{C}\right)$. Components not rated for the specified conditions shall be housed in a cabinet that provides a suitable operating environment.

All "wetted" components shall be compatible with a ventilation air stream characterized by high relative humidity (up to 100\%) and temperatures ranging from $40^{\circ} \mathrm{F}$ to $150^{\circ} \mathrm{F}$. In addition, the "wetted" components shall be compatible with varying amounts of hydrogen, nitrous oxide, methane, and ammonia vapors as minor constituents of the air stream.

The system shall be designed and installed to facilitate routine maintenance, including ease of removal and calibration of components. Sufficient isolation 
valves shall be provided to isolate instruments from the ventilation airstream and to enable calibration and maintenance.

The system design shall include provisions for periodic calibration and functional testing of interlock functions, and shall provide means to calibrate and test components in place without shutting the ventilation system down. Self-diagnosing and self-testing features shall also be considered to facilitate maintenance.

Component and tubing supports shall be provided to resist, as a minimum, the seismic and other natural phenomena loads defined in RPP-PRO-97 for general service or "PC1" SSCS, except that structures supporting safety related components shall be evaluated against "PC3" wind loads. The applicability of the "PC 3 " wind-generated missile criterion is the subject of an ongoing evaluation and will be applied as directed by the CH2M-Hill Hanford Group, Inc. (CHG) Chief Engineer.

\subsection{Civil Engineering and Site Work}

The $\Delta P$ interlock system shall be designed to minimize the extent of excavation or other site work required for its installation. Prior to release of the initial system design, the system "footprint" and interfaces shall be reviewed for necessary clearances and constructability, at least for the proposed seven initial installations (see Section 7.1).

\subsection{Mechanical Engineering and Materials}

Materials shall be traceable to ASTM standards, vendor information, or other documentation for any properties (e.g., chemical compatibilities, yield strength) that are relied upon in the design, or that could significantly affect system performance.

Tubing, fittings, and valves shall be made of materials selected for compatibility with the outdoor environment and the ventilation air stream (see also Section 4.3). Tubing runs shall be minimized and sloped to drain back to the ventilation ductwork, where practical, to prevent condensed moisture from collecting at low points in the system. Heat trace shall be provided on tubing runs as necessary to prevent freezing of condensed moisture.

\subsection{Electrical, Instrumentation, and Controls}

Electrical power components shall be purchased as Underwriter Laboratories (UL) listed equipment. The final cabinet assemblies shall comply with the current site-adopted revision of NFPA 70, National Electric Code (NEC). A11 wiring shall comply with the NEC, and shall be accomplished without use of splices. In addition, the final cabinet assemblies shall be certified and accepted in accordance with the requirements of the Hanford Electrical Safety Program (HESP 2000). 


\subsection{Safety}

The $\Delta \mathrm{P}$ interlock system shall be designed with the intent to minimize environmental releases and worker exposure to As Low As Reasonably Achievable (ALARA) during installation, operation, and maintenance of the system.

\subsection{Human Engineering}

The system shall be designed with consideration of human factors, encompassing such ergonomic factors as accessibility of valves and equipment for maintenance and operation, display readability, and method of recording data. The design shall also consider features that enable remote monitoring and diagnostics, or minimize surveillance and maintenance time required in field.

\subsection{Qualification}

A process shall be used to ensure that the system can perform its safety function reliably, under the stated operating conditions. Methods of qualification may include inspection or testing.

\subsection{QUALITY ASSURANCE}

Where applicable, equipment shall be procured as Safety Class and Quality Leve1 "1" (QL-1), with appropriate documentation. Instrumentation shall be appropriately certified by the manufacturer. The system shall be acceptance tested prior to installation in the field.

A quality assurance (QA) process shall be followed in the design, procurement, and installation of the system. The QA process shall address required tests or inspections, component traceability requirements, vendor evaluated supplier qualification needs, and Commercial Grade Item dedication needs (as appropriate). This $Q A$ process shall be in accordance with current RPP QA programs and policies, including RPP-MP-599 and HNF-IP-0842, Vol. XI, Sec. 1.1. The QA process for the PLC control program shall be implemented in accordance with software QA requirements of RPP-PRO-309.

\subsection{TURNOVER}

Acceptance for beneficial use (ABU) of the HEPA filter $\triangle P$ interlock system must meet requirements of HNF-IP-0842, Vol. IV, Sec. 3.12. An ABU checklist is included in Engineering Task Plan RPP-6180. 
RPP-5977, Rev. 0

\subsection{APPENDICES}

\subsection{List of Affected Exhausters}

Exhausters are identified by both a stack number and a facility or ventilation system description. The following is a list of 19 exhausters where the proposed $\Delta P$ interlock system installations are planned (from Gustavson 2000):

\begin{tabular}{|c|c|c|c|}
\hline STACK NUMBER & FACILITY OR SYSTEN DESCRIPTION & $\begin{array}{c}\text { NUMBER OF } \\
\text { FILTER } \\
\text { TRAINS }\end{array}$ & $\begin{array}{c}\text { NUMBER OF } \\
\text { EXHAUST } \\
\text { FANS }\end{array}$ \\
\hline $296-A-25$ & 244-A DCRT EXHAUSTER & 2 & 1 \\
\hline *296-A-26 & 204-AR UNLOADING FACILITY & 1 & 1 \\
\hline *296-A-27 & 241-AW PRIMARY & 2 & 2 \\
\hline *296-A-29 & 241-AN PRIMARY & 2 & 2 \\
\hline$* 296-A-40$ & 241-AP PRIMARY & 2 & 2 \\
\hline *296-A-42 & 241-AY/AZ PRIMARY & 2 & 2 \\
\hline $296-B-28$ & 244-BX DCRT EXHAUSTER & 3 & 1 \\
\hline *296-C-05 & 244-CR VAULT EXHAUSTER & 1 & 2 \\
\hline $296-C-06$ & $241-C-106(W-320 / W R S S)$ & 1 & 1 \\
\hline $296-P-16$ & 24l-C-105/106 TANKS & 1 & 1 \\
\hline *296-P-23 & 241-SY PRIMARY & 2 & 2 \\
\hline $296-P-28$ & 241-SY BACKUP & 1 & 1 \\
\hline $296-P-32$ & RMCS \#A (244-AR VAULT TANKS) & 1 & 1 \\
\hline $296-P-33$ & RMCS \#B PORTABLE & 1 & 1 \\
\hline $296-P-34$ & RMCS \#C PORTABLE & 1 & 1 \\
\hline $296-S-15$ & 241-SX TANKS & 1 & 2 \\
\hline $296-S-22$ & 244-S DCRT EXHAUSTER & 2 & 1 \\
\hline $296-S-25$ & 241-SY PRIMARY (NEW) & 2 & 2 \\
\hline $296-T-18$ & 244-TX DCRT EXHAUSTER & 3 & 1 \\
\hline
\end{tabular}

The seven stacks marked with an asterisk $\left(^{*}\right)$ are slated for $\Delta p$ interlock upgrades during FY-2000; the remainder will be completed in the following fiscal year. It should be noted that this is a tentative listing, as safety analysis revisions and various project activities are currently ongoing which may obviate the need to upgrade one or more of the above exhausters (or change the order in which the upgrades are executed). 
RPP-5977, Rev. 0

\subsection{Reference Drawings}

The following is a partial listing of affected drawings, by system. A more complete listing will be developed in the course of definitive design. Note, the saltwell portable exhausters (296-P-43, 44, \& 45) are not in the scope of the subject upgrades. However, these exhausters currently feature PLC-based HEPA filter $\triangle P$ fan interlock capability, and were listed as reference drawings due to their similarity with the proposed system.

296-A-26/204-AR Waste Unloading Facility:

H-2-70695, Electrical Elementary Diagrams, Wiring Diagrams, Wire Run List and Conduit Schedule.

H-2-70696, HVAC Schedules, Diagrams, and Details.

H-2-70697, HVAC Plan, Sections, and Details.

$\mathrm{H}-2-70701$, Instrumentation Plan, Sections, and Details.

H-2-79852, Electrical Power Plan First Floor.

$\mathrm{H}-2-85195$, Electrical One Line Diagram.

H-2-92187, Air Monitor and Control Installation and Wiring Diagrams.

296-A-27/241-AW Primary:

$\mathrm{H}-2-70324$, Sheet 5, Electrical Plans and Details.

H-2-70325, Sheets 2 \& 4, Electric Power and Control Elementary Diagram.

H-2-90909, HVAC - KI System Equipment Schedules and Notes.

H-14-020102, Ventilation Tank Primary System (VTP) 0\&M System P\&ID.

H-14-030002, Electrical (EDS) One-Line Diagram.

296-A-29/241-AN Primary:

H-2-71925, Electrical Power and Control Plans and Details.

H-2-71927, Electrical Power and Control Elementary Diagrams.

$\mathrm{H}-2-71959$, Instrumentation Annunciator Elementary Diagram.

H-2-71937, HVAC Equipment Schedules, Details, and General Notes.

H-14-020101, Ventilation Tank Primary System (VTP) 0\&M System P\&ID. 
296-A-40/241-AP Primary:

H-2-90470, Electrical Power Distribution Plan, Sections, and Details.

H-2-90476, Electric Elementary Diagrams Central Exhauster Station.

H-2-90477 (Sh. 10 \& 11), Electrical Wire Run List, Central Exhaust Station.

H-2-90480, Electrical Relay Enclosures.

H-2-90516, HVAC Central Exhauster Station Primary System.

H-2-90522, HVAC Equipment Schedules and Notes.

H-2-90750, HVAC Details.

H-2-99085, Electrical Elementary Diagrams.

H-14-020103, Ventilation Tank Primary System (VTP) O\&M System P\&ID.

H-14-030003 (Sh. 3), Electrical (EDS) One-Line Diagram.

H-14-030003 (Sh. 16), Electrical (EDS) Panelboard Schedule.

296-A-42/241-AY/AZ Primary:

H-2-131266, HVAC Ventilation Facility Floor Plan.

H-2-131271, HVAC Equipment Schedules.

H-14-020107, Ventilation Tank Primary System (VTP) 0\&M System P\&ID.

\section{6-C-05/244-CR Vault:}

H-2-33279, Stack Gas Filter Arrangement.

H-2-41745, Heating and Ventilation Plan - Ductwork to Filter and Stack.

H-2-41746, Heating and Ventilation Sections - Ductwork to Filter and Stack.

H-2-41781, Heating and Ventilation Plan and Sections - Stack Exhaust Fans and Platforms.

H-2-95308, Stack Gas Filter and DP Connector and Stand Assembly.

\section{6-P-23/241-SY Primary:}

H-2-37744, Ventilation Air Flow and Control Diagram.

$\mathrm{H}-2-37745$, Ventilation Equipment Assembly.

H-2-37746, Ventilation Equipment Plan and Details. 


$$
\text { RPP-5977, Rev. } 0
$$

H-2-37747, Ventilation Equipment Schedules.

H-14-020131, Ventilation Tank Primary System (VTP) O\&M System P\&ID.

H-14-030031, Sheet 2, Electrical (EDS) One-Line Diagram.

\section{6-S-15/241-SX Tanks:}

H-2-35834, Vent Air Flow Diagram Tanks SX-105, 107, 108, 109, 110, 111, 112, and 114 .

H-2-35835, Ventilation Plan and Details Tanks SX-105, 107, 108, 109, 110, 111, 112 , and 114 .

H-14-020134, Ventilation Tank Primary System (VTP) O\&M System P\&ID.

\section{6-S-22/244-S DCRT:}

H-2-71047, Ventilation Air Flow and Control Diagram and Schedule.

H-2-71048, Ventilation Plan and Details.

H-2-71085, Instrumentation Engineering Flow Diagram.

H-2-71090, Electrical Plans and Details.

H-2-71092, Electrical Diagrams and Details.

H-14-030053, Electrical (EDS) One-Line Diagram.

\section{6-T-18/244-TX DCRT:}

H-2-73796, Engineering Flow Diagram System No. 1.

H-2-73819, Electrical One-Line and Elementary Diagram System No. 2.

1-2-73838, HVAC Airflow and Control Diagram and Schedule.

H-2-73839, HVAC Plans, Sections, and Details.

\section{6-P-43844\&45/500-CFM Saltwell Portable Exhausters}

H-2-829116, 500 CFM Portable Exhausters Piping and Instrument Diagram.

H-14-100868, Electrical Exhausters B, C, and D One-Line Diagram.

H-14-100869, Electrical Exhausters $B, C$, and D Parts List and General Notes.

H-14-100870, Electrical Exhausters B, C, and D Skid Details and Parts List. 


\section{DISTRIBUTION SHEET}

To

Distribution

Project Title/Work Order

RPP-5977, HEPA Filter Differential Pressure Fan Interlock system

Functional Requirements and Technical Design Criteria

Name

D. G. Baide

K. E. Carpenter

R. D. Gustavson

T. D. Kaiser

R. E. Larson

C. M. Lewis

J. Lohrasbi

C. C. Scaief III

D. Scott Jr.

R. R. True

J. A. Tuck

W. E. Willingham Jr.

Jonathan Young

S.G. Smith

N.J. Harville
From

RPP - Operations special Projects

|

\section{MSIN}

s5-05

R3-47

R3-83

T4-07

T4-07

R3-47

S5-05

R3-83

55-07

T 4-07

R3-47

L6-37

K7-97

L6-37

R3-47

\begin{tabular}{c|c|}
\hline Text & \\
With All & Text Only \\
Attach. &
\end{tabular}

With All
Attach.

$\mathrm{x}$

$\mathrm{X}$

$\mathrm{X}$

$\mathrm{X}$

$\mathrm{X}$

$\mathrm{X}$

$\mathrm{x}$

$\mathrm{X}$

$x$

$x$

$\mathrm{x}$

$\mathrm{x}$

$x$

$\frac{x}{x}$

$x$

$x$

Date 11 April 2000

EDT No. 626597

EDTNo. 626597

\begin{tabular}{|c|c|}
\hline $\begin{array}{c}\text { Attach./ } \\
\text { Appendix } \\
\text { Only }\end{array}$ & $\begin{array}{c}\text { EDT/ECN } \\
\text { Only }\end{array}$ \\
\hline & \\
\hline & \\
\hline & \\
\hline & \\
\hline & \\
\hline & \\
\hline & \\
\hline & \\
\hline & \\
\hline & \\
\hline & \\
\hline & \\
\hline & \\
\hline & \\
\hline & \\
\hline & \\
\hline & \\
\hline & \\
\hline & \\
\hline & \\
\hline & \\
\hline & \\
\hline
\end{tabular}

